\section{Living borders as an alternative for the development of the northern zone in the province of Esmeraldas, Ecuador}

Fronteras vivas como alternativa para el desarrollo de la zona norte en la provincia de Esmeraldas, Ecuador

\section{Félix Aníval Preciado Quiñónez *}

\section{ABSTRACT}

This paper deals with the situation of violence in the San Lorenzo canton located in the northern part of the province of Esmeraldas on the Ecuadorian border with Colombia. The objective of the research is the construction of a peace zone as an alternative to achieve the development of these towns. The methodology used is based on a historical-logical type of research, using qualitative techniques based on participatory observation instruments, documentary sources and bibliographic review. The results and discussion indicate that the institutions that finance and carry out this type of research are located in the city of Quito, which allows us to understand the reasons why there is no follow-up on the different types of violence and its manifestations. The conclusions indicate that these conflicts should have been prevented and that there is no local development strategy on the northern border of the province. The Ecuadorian state is primarily responsible for not confronting the violence by not formulating comprehensive proposals for the development of the border zone within the framework of national security.

Keywords: borders, development, northern zone, Esmeraldas, development, Esmeraldas

\footnotetext{
* Master's Degree, Full Professor, Universidad de Esmeraldas Luis Vargas Torres felix.preciado@utelvt.edu.ec https://orcid.org/0000-0003-3789-6835
}

JOURNAL OF BUSINESS and entrepreneurial studies ISSN: 2576-097|

Atribución/Reconocimiento-NoCo mercial- Compartirlgual 4.0 Licencia Pública Internacional — CC

\section{BY-NC-SA 4.0}

https://creativecommons.org/licenses /by-nc- sa/4.0/legalcode.es

Journal of Business and entrepreneurial January - March Vol. 6 - I - 2022 http://journalbusinesses.com/index.php/revista e-ISSN: 2576-097I

journalbusinessentrepreneurial@gmail.com Receipt: I I April 202 I

Approval: 02 July 2021

Page 55-64 


\section{RESUMEN}

El presente trabajo trata sobre la situación de violencia en el cantón San Lorenzo localizado en la zona norte de la provincia de Esmeraldas en la frontera ecuatoriana con Colombia. El objetivo de la investigación consiste en la construcción de una zona de paz como alternativa para alcanzar el desarrollo de estos pueblos. La metodología empleada se fundamenta en un tipo de investigación histórico-lógica, donde se emplean técnicas cualitativas basada en instrumentos de observación participativa, fuentes documentales y revisión bibliográfica. Los resultados y discusión realizados indican que las instituciones que financian y realizan este tipo de investigaciones se encuentran en la ciudad de Quito, lo que permite comprender las razones por las cuales no hay seguimiento sobre los diferentes tipos de violencia y sus manifestaciones. Las conclusiones indican que estos conflictos debieron ser prevenidos y que no existe una estrategia de desarrollo local en la frontera norte de la provincia. El estado ecuatoriano es el principal responsable de no enfrentar la violencia por no formular propuestas integrales para el desarrollo de la zona fronteriza en el marco de la seguridad nacional.

Palabras clave: fronteras, desarrollo, zona norte, Esmeraldas

\section{INTRODUCTION}

The province of Esmeraldas, located in the north of the Republic of Ecuador, bordering the Republic of Colombia in the cantons of San Lorenzo and Tumaco, has been the scene in the last six years of events that, due to their characteristics, have achieved international renown. This paper presents some reflections in relation to the situation of violence in the northern area of the province of Esmeraldas, specifically in the canton of San Lorenzo and the construction of a peace zone as the only alternative to achieve the development of these people who have been victims of extreme poverty and exclusion from the social and economic point of view and throughout the history of Ecuador.

For Vargas \& Rodríguez (2013) the treatment of issues related to security, more than a fashion, currently constitutes a novel space for academic reflection, applied research and political debate for the different social disciplines that, from varied theoretical and methodological approaches, influence the design of public policies for States and societies.

The northern part of the province of Esmeraldas has been subject to growing social instability in the last decade due to the presence of armed actors who cross the Ecuadorian border from Colombia to escape persecution by the Colombian army, to rest or to carry out activities related to illicit business. This situation has worsened as a result of the geo-strategy developed by the Colombian regime under the government of President Álvaro Uribe as part of Plan Colombia, known as "Democratic Security".

Although the international community had observed the Colombian conflict as an internal matter, it was not until the events of Operation Fénix, also known as the Angostura bombing in 2008, that the escalation of the Colombian conflict and the 
diplomatic tensions between Quito and Bogotá as a result of this unilateral action by the Colombian army in an open violation of Ecuadorian sovereignty, which led to complaints and denunciations by the Ecuadorian government, the Colombian conflict acquires a new dimension on the Ecuadorian side and the focus of attention of the international community is directed towards the nature of the conflict, making it transcend the internal logic and become a problem that threatens the stability of the region.

\section{MATERIALS AND METHODS}

The methodology used is based on a qualitative type of research based on documentary sources, bibliographic review and participatory observations. Historical-logical methods make it possible to organize and analyze the information.

This paper also uses the theory of interdependence and analyzes the relations between the two states and their growing military and police relationship, within the framework of national security. In the 1970s, complex interdependence became one of the classic paradigms for explaining the international relations of the new actors that appeared on the world scene.

Authors such as O'Shea-Cuevas et al. (2015) assume that the model of "complex interdependence" is the model of power and their critique of the realist conception of power. A certain definition of the realist vision of power is discussed, which leads to privileging certain types of actors over others and to requiring specific attention to certain issues and not others. By interdependence, according to Riquelme et al. (2017) should be understood as follows. In common parlance, dependence means a state in which one is determined or significantly affected by external forces. Interdependence, in its simplest definition, means mutual dependence. Interdependence in world politics refers to situations characterized by reciprocal effects between countries or between actors within countries."

According to Accinelli \& De la Fuente (2013) there is a tendency in the constituent parts of sovereign states to participate in international cooperation from a secondary decisionmaking level due to the need to consolidate spaces to respond to their local needs. In this sense, it can be seen that the northern border area of the province of Esmeraldas with Colombia poses conflicts in a relationship of local and highly complex interdependence, beyond the national policies and national legal frameworks of Ecuador and Colombia.

The research is oriented in three dimensions, the first one presents a diagnosis of the canton of San Lorenzo in the province of Esmeralda and the impact that the conflict has had on its population. The second topic is oriented to demonstrate the abandonment of the people living on both sides of the border by the governments of Ecuador and Colombia and how this abandonment conditions the structural conditions of poverty and violence in the area. The third theme explores some proposals as alternatives to guarantee peace on the border and ensure its development.

Geographically, Colombia's border with Ecuador is made up of three natural zones: Amazonian, Andean and Pacific. The northern border covers three provinces: 
Sucumbíos, Esmeraldas and Carchi. This immense corridor has been an area abandoned by the States. This is a consequence of the country's historical trajectory (its state conformation process, its economic development, its demographic expansion, among others). But it is also the result of public policy decisions and a centralized territorial organization model (which has encouraged and even reinforced the peripheral nature of cities far from the center of power).

San Lorenzo, a natural port 18 kilometers from the Colombian border, is strongly influenced in its economic strength by illicit crops on the Colombian side, which produce the money that moves in San Lorenzo and arrives by different routes, without being traced by the competent authorities. The transformation of the formal economy of San Lorenzo into a subway economy of money laundering through the purchase of food and subsistence products such as arms and ammunition for the irregular groups operating on the border. Extreme poverty and the lack of institutions have left the population vulnerable to the various armed actors that swarm in the region and in the hands of the most diverse illicit activities, which proliferate in the absence of the state.

According to Ecuador's Population and Housing Census, there are 62,772 inhabitants in San Lorenzo, $84.59 \%$ of whom live in extreme poverty. These figures reveal the reasons for the area's vulnerability to the Colombian conflict.

If the central power has been absent, no less is the responsibility of the local authorities, who, under any argument, deny their responsibility in the face of the abandonment of their populations. The low quality of local government, its lack of articulation between the different territorial levels, the convergence of local governance with the national level, its scarce integration with national dynamics (political, economic, cultural), and the limited governance capacities available to the authorities (due to factors as diverse as scarcity of resources or incompetence of officials) have an evident impact on the appearance of abandoned territories which then become ungoverned territories taken over by armed actors engaged in illicit activities who coerce the inhabitants and turn them into operators of their illicit activities.

The San Lorenzo canton on its border with Colombia was not always like this. Historically it was an area of calm confluence, meeting points for families from both sides of the border, expressions of culture and commercial exchange between our two countries, a mechanism of fraternal relationship and collective brotherhood, this border expressed the best of the intrinsically peaceful and creative nature of its inhabitants. This history of encounter, brotherhood and social and cultural familiarity has been subtracted and its existence undermined, both by the abandonment of the State, as well as by the presence of new social actors outside the law.

It is proposed because Guinot (2017) that our countries have a common border of 600 kilometers, and have several passes in the middle of rivers, mountains or jungle, due to the ruggedness of the area, which are access routes, free of border control by the authorities, a situation that has led to a significant passive infiltration of Colombian guerrillas and narco-guerrillas in our territory. Colombian guerrillas use Ecuador as a refuge. Vallejos et al. (2013) points out that unfortunately for all America, the problem 
of our sister Republic of Colombia instead of weakening, worsened and tends at various times to a painful victimization of innocent people, in addition to becoming the unjustifiable revolutionary cause of the insurgent groups, which are the armed wing of drug trafficking.

However, despite all these arguments of impact on Colombian society, Ecuador is the border country that has felt the effects of Plan Colombia the most, either due to the growing social violence in the border areas, the increase in insecurity, the impoverishment of the border provinces due to the decrease in informal trade with Colombia's neighbors, environmental and health damages as a consequence of glyphosate spraying on crops near the border area, increased migration, displaced persons and refugees, and in terms of national security, mainly due to what has been called "the impact of Plan Colombia", environmental and sanitary damages as a consequence of the fumigations with glyphosate in the crops near the border area, increase of migration, displaced people and refugees, and in the National Security area, mainly due to what has been called the "Anvil Effect", which is a war term used for jungle operations where there is no defined front. With raking patrols, enemy bases are occupied and areas are cleared. In this case, the Colombian forces do the hammering, the permanent pressure for the guerrillas to go south where Ecuador makes the strategic anvil on its border. There they have a strong presence with military, police and intelligence personnel. It is a way to dissuade the subversives from entering Ecuadorian territory in a clandestine manner. It also prevents guerrilla forces from receiving supplies and medical attention.

Border zones are particularly sensitive, vulnerable and not very resilient. This vulnerability is due to various factors, such as the multidimensionality of their peripheral nature and the asymmetries that exist on both sides of the border. Border areas merit special attention from the States as a whole. They are in the process of incorporating a "differential, comprehensive and comprehensive border approach in the design, adoption and implementation of policies in a wide range of areas: international trade, infrastructure, environment, education, mobility and transportation, health, border integration agreements in operation, dynamic border markets, full exercise of governments of local authorities, participation of the population in development plans and projects, border regions articulated through corridor systems and invigorated economic centers, eradicating extreme poverty, employment rates at adequate levels, poor families improving their social status, educational training based on local cultures, facilitating the development and integration of individuals, families, the community and society, and facilitating competitive insertion into the labor market.

This orientation implies a real commitment to developing instruments provided for in national legal frameworks, implementing public diplomacy strategies with relevant and diverse actors in the border areas of the respective countries.

Too often, border issues are confused with boundary issues (delimitation, demarcation, external defense) or with cross-border dynamics. Although both have an influence on border issues, they are not synonymous with them, nor can they be reduced to one of 
them. The sensitivity of borders is often beyond the control of the government and the authorities, as it may be due to real externalities. Therefore, a comprehensive border policy should focus above all on reducing vulnerabilities (which do depend mainly on internal capacities, resources and procedures) and increasing their resilience (their capacity to recover from the negative impact of externalities and to compensate for variations in binational relations). This, in turn, implies generating a high degree of adaptability to the changes inherent to border dynamics.

One of the characteristics of most border areas in Latin American countries is their remoteness from the major centers (economic, social, cultural, political). This only reinforces their peripheral situation and marginality. The Colombian conflict

Basically, a border could be defined as a more or less permeable area through which two spaces that are supposed to be different come into contact. They can be political, economic and/or cultural borders, which are differentiated materially and symbolically. From this generic perspective, the border can be thought of as a space of social production and a means for the reproduction of social relations between the set of inhabitants living on either side of the extensive geography that separates them.

The northern border in the province of Esmeraldas has been associated with any illicit activity that transcends the boundaries of the counterinsurgent state, designed since the cold war and still present in the security policies promoted by the governments of the two states, both on the Ecuadorian and Colombian sides.

This biased vision of what borders really are and the role they play in the process of twinning of our two peoples, is permanently hindered by the militarization that takes place there, invoking the multiple phenomena that constitute it, without taking into account the specific characteristics of the area and that determine its nature.

The first particularity is that being a border, by itself, already constitutes a factor that complicates the scenario for understanding the problems of violence, poverty and social exclusion, because it raises confusing conceptual debates that mostly express centralist visions about the problems of violence without providing solutions. But it is from the political side where the debate occupies a central place in the debate on violence in the border area and is usually related to the defense, security and foreign policy measures implemented by the States to deal with these particularities, without addressing the demands of the populations. But border problems go beyond the sphere of violence and are rooted in the social and economic structure of the populations that inhabit it and demand a different approach. From this perspective, the border is manifested in several social dynamics, which we will address. The massive displacement of Colombians to the northern border in the province of Esmeraldas in search of refuge, although influenced by the armed conflict, is not the only factor that conditions it. There are multiple interactions that explain the massive presence of Colombians on Ecuadorian soil, including economic causes, which makes it difficult to differentiate between primary and secondary causes as a fundamental factor of the migratory phenomenon. In other words, the migratory phenomenon is not a limited issue that must be justified solely on the basis of the violence exercised by state bodies and groups acting outside the law. 
Throughout the Republican history, the province of Esmeraldas has been a recipient of citizens who pass from the Colombian side to the different cantons of the province and who find in San Lorenzo, the ideal geographical space for the beginning of their new life. This fact is due to the successive transformations that have taken place in the political, economic and social structure of Ecuador in the last 50 years of democracy. These transformations allowed the country to become a place of easy access due to the migration policies implemented and the dollarization of its economy.

According to Monarca (20I3)According to the Colombian government, San Lorenzo is currently home to 14,000 Colombian refugees out of a population of 62,000 . About $60 \%$ of asylum seekers in Esmeraldas consider themselves Afro-Colombian. Many people of the indigenous Awá nationality live in border communities in Esmeraldas. In these places the population has reduced access to basic services and socioeconomic development is limited.

It is from 2008 that the right to refuge is enshrined and the government is forced to build a public policy on refugee protection, strengthening the institutional capacities of the Ministry of Foreign Affairs, which is forced to decentralize some of its new powers, installing an office in San Lorenzo. Under this new approach, a roadmap was designed with different plans aimed at building a comprehensive refugee policy, as well as the design of a policy to guarantee the rights and legalization of refugees. These policies worked until 2016, when the institutions that supported these policies were dismantled, under the argument of the lack of economic resources to meet the growing needs arising from the massive immigration from both Colombia and Venezuela.

Drug trafficking is undoubtedly the biggest problem in the Colombian-Ecuadorian border area, because it is interrelated with national security as it is linked to the Colombian conflict, which has led to a greater development of illicit crops, narcotic substances and their commercialization by armed groups and coca traffickers in the ColombianEcuadorian border area, The persecution of these groups by the Colombian army and the spraying of glyphosate on crops on the Colombian side of the border has pushed them towards border territories that are less militarized by the Ecuadorian state.

Understood as a criminal figure, drug trafficking, while appropriating territories through violence, recreates its own activities such as cultivation, processing, trafficking, consumption and related activities such as: murder of people, illicit enrichment, money laundering, illegal possession of weapons, kidnapping, extortion, etc., which have altered the concept of borders, as they were designed with the constitution of the nation states. These borders have been altered by the presence of these new violent actors, who impose their logic of death, displacement and violence on a population under fire from members of the army and irregular groups of all stripes.

The alteration of the border in terms of social production has undermined social stability, peace and peaceful coexistence, being subjected to a permanent militarization which obstructs the construction of a citizenship project, capable of challenging the threats posed by the presence of these transnational armed actors, which justifies the 
militaristic policies of the two states, creating greater interdependence in security relations in the border area.

This clear military interdependence between Colombia and Ecuador would not be possible without the role of the United States in the border conflict. The role that this country plays on the northern border is not only related to drug trafficking, as is clear from the objectives of Plan Colombia, but also within its strategy of intercontinental security and the fight against the insurgent forces expressed in the FARC and ELN and the military defeat of these guerrilla organizations.

However, the military presence of the United States on the northern border, under the assumption of fighting drug trafficking, far from contributing to its pacification, has incorporated new elements of contradiction and conflict. If it is taken into account that since 2008 between the government of the United States and Colombia, not only cooperation agreements and technical assistance in Defense and Security have been signed, but also the settlement of part of the U.S. armed forces in Colombia through seven military bases located in strategic sectors of the Colombian geography, all in the name of the national security of the United States, This has warmed not only the territorial space where these forces operate, but also the entire region, whose governments feel that the sovereignty of their States is seriously threatened by the militaristic and warlike policy implemented by the United States as part of its neocolonial expansion geopolitics.

The northern border of Esmeraldas has not become dangerous by the will of those who live there, but as a result of militaristic policies designed and promoted from both sides of the border, as counterinsurgency policies aimed at combating the internal enemy.

These policies, more than a decade after their implementation, have not met the objectives set by the U.S. and its Colombian and Ecuadorian allies. The planting, cultivation, commercialization and trafficking of cocaine has quadrupled since the implementation of Plan Colombia. Although the peace agreements between the FARC and the Colombian government gave rise to the optimism that pacification was possible and viable, these forecasts have not been fulfilled either. Meanwhile, the border is becoming more dangerous every day, not only because of the existence of the phenomena already described, but also because of the absence of a country project that links the peripheral sectors to the development plans and incorporates them into the late capitalist modernity.

\section{RESULTS}

\section{Alternative for development}

A Plan for San Lorenzo and the entire border area is a proposal that could be viable, if several fronts rehearse a path for the development and sovereign defense of Ecuador, that is to say, a plan designed from several axes: the diplomatic axis, based on the principle of non-intervention and respect for the free development of the peoples, in favor of Andean integration, keeping the common heritage that unites these brotherly peoples; the axis of national and international internal security, through the organs of 
the Public Force and its involved agencies; the axis of civil society and human development for progress, under a dynamic process oriented to production, commercial exchange, infrastructure, basic services, etc. The political axis, in concomitance with the axis of civil society and state, provincial and local agencies responsible for the implementation of appropriate social policies for local development.

The physical, economic, political, social and cultural integration of border areas must be a priority. There is no shortage of tools to generate greater integration in these areas. The effort to achieve this objective can open up opportunities for synergy between public administrations, for cooperation with the private sector, for institutional improvement; and, along the way, can provoke a positive spillover effect. The fulfillment of some of the objectives developed will ensure the presence of borders, alive and dynamic, within everyone's reach and far from the conflicts that arise.

The actions and policies developed by the Ecuadorian State have focused on national defense. These actions are aimed at preventing the spillover of the Colombian conflict, a solution to the permanent insecurity caused by the presence of armed actors of all kinds. Now, the problem lies in the permanent distrust that the population has for the actions of the State in terms of security policy, in the absence of answers to the most pressing needs such as public services, health, education, employment and housing.

After World War II, the harmonization of policies among many countries has been focused on development cooperation, as promulgated by the United Nations: To achieve international cooperation in solving international problems of an economic, social, cultural or humanitarian character, and in promoting and encouraging respect for human rights and fundamental freedoms for all.

These basic rights guaranteed in the 2008 Constitution of the Republic of Ecuador are not part of the proposals in the short or medium term of state policies to solve the unresolved problems that centuries of neglect have accumulated in the populations on both sides of the border. One of the justifications put forward by all governments has been the lack of economic resources to meet the unsatisfied basic needs of the vast northern border. This justification is disproved when one observes the military presence. There is money for militarization, but not for the people living on the threshold of poverty.

The creation of a State public policy for these zones is the appropriate way to face the challenges of this changing frontier. The improvement of the living conditions of the population is also conditioned to the creation of a new democratic economy that stimulates the participation of the broadest sectors in an economic proposal for peace and development. This new economy must be based on the provision of long-term, lowinterest loans, so that those who benefit can undertake the task of incorporating themselves into the local productive process, generating new jobs and new synergies in the region, with actors who are committed to breaking out of the cycle of violence and the underground economy. This must be accompanied by a greater presence of state agencies and their management capacity. 


\section{CONCLUSIONS}

There is an extensive and diverse historical memory on studies of the northern border in the province of Esmeraldas. These studies are focused on the issues of refuge, violence and drug trafficking. The institutions that finance and carry out this type of research are located in the city of Quito, which allows us to understand the reasons why there is no follow-up on the different types of violence and its manifestations. Regarding violence and how to face its challenges, it is indisputable that the Ecuadorian State is the main responsible in this matter for not having been concerned in the elaboration and application of integral proposals for the development of the border zone and not limiting the military variable within the framework of national security.

\section{REFERENCES}

Accinelli, E., \& De la Fuente J. L. (20/3). Corporate social responsibility, business activities and sustainable development Mathematical model of business decisions. Accounting and Management, 58(3), 227-248. https://doi.org//0.1016/s01861042(13)7 I228-2.

Guinot, H. V. (20I7). Review. Estudios Políticos, 42, I7I-I75. https://doi.org/I0.10I6/j.espol.2017.10.006.

Monarca, H. (2013). Dialogic participation in the university: condition for the development of critical thinking and social commitment. Revista lberoamericana de Educación Superior, 4(9), 53-62. https://doi.org/l0.1016/s2007-2872(13)71916-4.

O'Shea-Cuevas, G., Rizzoli-Córdoba, A., Aceves-Villagrán, D., Villagrán-Muñoz, V. M., Carrasco-Mendoza, J., Halley-Castillo, E., Delgado-Ginebra, I., Pizarro-Castellanos, M., Vargas-López, G., Antillón-Ocampo, F. A., Villasís-Keever, M. Á., \& MuñozHernández, O. (20I5). Sistema de Protección Social en Salud para la detección y atención oportuna de problemas del desarrollo infantil en México. Boletin Medico Del Hospital Infantil de Mexico, 72(6), 429-437. https://doi.org/I0.1016/j.bmhimx.2015.10.002

Riquelme, A., Püschel, K., Díaz, L. A., Rojas, V., Perry, A., \& Sapag, J. (2017). Social responsibility in Latin America: path towards the development of an instrument for medical schools. Investigación En Educación Médica, 6(22), 135. https://doi.org/10.1016/j.riem.2017.01.135. https://doi.org/10.1016/j.riem.2017.01.135

Vallejos, C., Reveco, R., Bachelet, V. C., Goyenechea, M., Velasquez, M., de La Puente, C., Bustos, L., \& Zaror, C. (20I3). Evaluación Costo-Efectividad Y De Valor Social De Un Programa De Intervención En Población Infantil En Situación De Vulnerabilidad, Rezago O Déficit En El Desarrollo Integral - Chile 2012. Value in Health, I6(7), A7I0. https://doi.org/I0.1016/j.jval.2013.08.2182

Vargas, G., \& Rodríguez, C. M. (2013). A microeconomic analysis of the effects of innovation on development and social welfare. Economia Informa, 383, 64-76. https://doi.org/10.1016/s0185-0849(I3)7I34I-0. 
